\title{
PREFERENSI KONSUMEN DAN STRATEGI PEMASARAN PRODUK OLAHAN KELAPA KOPYOR
}

\author{
Valentina Sokoastri \\ PT. Riset Perkebunan Nusantara, Jl. Salak No. 1A, Kota Bogor-Jawa Barat, Indonesia \\ 1)e-mail: valentina@rpn.co.id
}

(Diterima 5 Mei 2020 / Disetujui 24 Juni 2020)

\begin{abstract}
Many people like Kopyor coconut. Kopyor Coconut formed from an abnormal coconut fruit that is only be found in a rare number of the normal coconut tree. Unfortunately, the demand for kopyor coconut is not followed by the supply, in other words, the supply of Kopyor Coconut is still under the demand. Following this opportunity, Indonesian Biotechnology Plantation Research Center, PT Riset Perkebunan Nusantara invented a plant tissue isolation method that can produce 90 to 100 per cent of kopyor coconut fruit. Thus, it is necessary to study consumer preferences and marketing strategy to distribute Kopyor product in the right plan. This study uses a quantitative approach by capturing 50 respondents in incidental sampling. The data is then processed descriptively using Microsoft excel to see consumer preferences and its $4 P$ (Product, Place, Promotion, Price). From the data analysis obtained as follows: 1. Consumer preferences of kopyor coconut (Kosudu) are quite well and acceptable by the costumers. 2. The product, place and promotion need to be regenerated, but for the price is quite stable. 3. Need marketing strategies to improve product quality, such as (brand, packaging, and quality control), place such as (online delivery system and retail approach, last but not least the promotions such as (discounts and advertising).
\end{abstract}

Keywords: kopyor coconut, preference, marketing strategy

\begin{abstract}
ABSTRAK
Kelapa kopyor adalah minuman yang banyak diminati oleh banyak orang. Kelapa kopyor sendiri terbentuk dari buah kelapa yang abnormal yang hanya terdapat di sebagian kecil pohon kelapa. Sayangnya produksi buah kelapa kopyor tidak sebanding dengan permintaannya, dengan kata lain supplay kelapa kopyor masih lebih sedikit dibandingkan dengan demandnya. Menanggulangi hal tersebut, Pusat Penelitian Bioteknologi Perkebunan Indonesia, PT Riset Perkebunan Nusantara telah menciptakan kultur jaringan pohon kelapa kopyor yang dapat menghasilkan buah kelapa kopyor dengan tingkat keberhasilan buah kopyor mencapai 90 sampai dengan 100 persen dalam satu pohon kelapa. Untuk menanggulangi supply kelapa kopyor yang akan semakin tinggi, maka diperlukan kajian preferensi konsumen dan strategi pemasaran produk kelapa kopyor untuk mengetahui penerimaan konsumen, sehingga supply kelapa kopyor yang dikembangkan dapat dipasarkan dengan strategi yang tepat. Penelitian ini menggunakan pendekatan kuantitatif dengan menjaring 50 responden secara incidental sampling. Data kemudian diolah secara deskriptif menggunakan Microsoft excel untuk melihat preferensi konsumen dan bauran pemasaran 4P (Product, Place, Promotion, Price). Dari hasil analisis data diperoleh kesimpulan sebagai berikut: (1) Preferensi konsumen terhadap produk kelapa kopyor (Kosudu) dari Pusat Penelitian Bioteknologi Perkebunan Indonesia cukup baik, yakni hampir 76 persen responden mengaku menyukai dan ingin membeli ulang Kosudu; (2) Pada bauran pemasaran harus memperbaiki unsur product, place dan promotion, namun untuk unsur price / harga sudah dipandang baik. Adapun strategi-strategi yang harus dilakukan untuk meningkatkan pemasaran kelapa kopyor adalah melihat dari segi product (merek, kemasan, kepraktisan, dan quality control), place (online delivery dan pemasaran yang luas), promotion (potongan harga dan iklan).
\end{abstract}

Kata kunci: kelapa kopyor, preferensi konsumen, strategi pemasaran

\section{PENDAHULUAN}

Kelapa kopyor merupakan komoditas perkebunan yang masih lambat pengembangannya, karena diperlakukan sebagai tanaman sekunder di antara tipe tanaman kelapa lainnya. Keadaan ini mengakibatkan aspek usaha tani, pemasaran, serta aspek ekonomi kelapa kopyor belum banyak diketahui Hutapea (2007). Padahal, harga buah kelapa kopyor sangat menjanjikan dan memiliki 
nilai ekonomi yang tinggi sehingga peluang bisnis dari budidayanya masih begitu besar.

Sampai saat ini memang masih belum tersedia data yang secara rinci menjelaskan tentang supply dan demand kelapa kopyor yang dikeluarkan oleh Direktorat Jenderal Perkebunan (2013) karena kelapa kopyor masih dianggap sebagai tanaman sekunder. Sifatnya yang abnormal dan tidak sebanyak jenis kelapa biasa, membuat harga kopyor tergolong jauh lebih mahal dari kelapa biasa. Pada tahun 2017, dilaporkan oleh Pusat Penelitian Bioteknologi Perkebunan Indonesia kemudian disingkat PPBBI, PT Riset Perkebunan Nusantara, harga satu buah kelapa kopyor berkisar antara Rp35.000 sampai dengan 45.000/ butir, sedangkan buah kelapa normal atau yang biasa disebut kelapa degan, berkisar antara Rp3.000 sampai dengan Rp4.000/butir. Saat ini konsumen kelapa kopyor masih tergolong eksklusif karena hanya dapat diminum oleh kaum menengah ke atas. Areal perkebunan kelapa kopyor lebih banyak ditanam di tanah tegalan atau tanah pekarangan, tetapi pada daerah transmigrasi di luar Jawa tanaman kelapa ditanam secara monokultur perkebunan kelapa Vinifera (2006).

Seiring dengan tingginya minat konsumen akan konsumsi buah kelapa kopyor dan peluang bisnisnya yang menjanjikan, PPBPI, PT Riset Perkebunan Nusantara telah mengembangkan kultur jaringan komoditas kelapa kopyor sehingga dapat menghasilkan 90\% sampai dengan 100\% buah kopyor. Hasil dari kultur jaringan tersebut dapat menyebabkan pertambahan supply dari buah kelapa kopyor karena dapat diproduksi secara lebih besar dan tidak perlu menunggu faktor abnormalitas buah seperti yang terjadi pada jenis kelapa normal. Untuk mengantisipasi kemungkinan peningkatan produksi, perlu dilakukan rencana pemasaran yang tepat untuk memasarkan daging buah kelapa kopyor di masa yang akan datang.

Pada awalnya buah kopyor yang diproduksi oleh PPBBI bukanlah untuk kebutuhan komersial, melainkan lebih mengutamakan embrionya untuk dijadikan bibit. Dengan kata lain daging buah kopyor yang dikonsumsi berasal dari produk samping embrio yang akan dimanfaatkan untuk pembibitan kopyor. Seiring dengan pertumbuhan permintaan yang semakin meningkat, muncul ide untuk mengembangkan daging buah kelapa kopyor menjadi produk olahan yang diberi nama Kosudu atau Kopyor Super Duper. Produk tersebut dijual kepada masyarakat. Hal ini kemudian mendapat respon sangat positif dari masyarakat dan konsumen yang sangat menyukai produk dari kelapa kopyor ini, sehingga PPBPI termotivasi untuk lebih menggencarkan pengembangan produk olahan kelapa kopyor tersebut untuk meningkatkan pendapatan perusahaan.

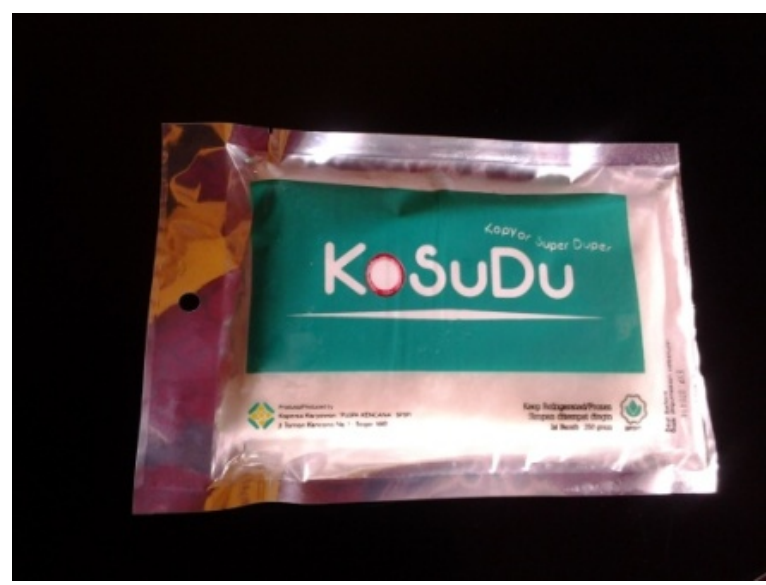

Gambar 1. Produk Olahan Kosudu dari PPBPI Sumber: PPBBI, 2017

Deskripsi produk olahan Kosudu produksi dari PPBPI dijelaskan dalam tabel 1 berikut ini:

Tabel 1. Deskripsi Produk Kosudu

\begin{tabular}{|c|c|}
\hline Item & Deskripsi \\
\hline Nama Produk & $\begin{array}{l}\text { Kopyor Super Duper } \\
\text { (Kosudu) }\end{array}$ \\
\hline Harga/pack & Rp28.000/pack (250 gram) \\
\hline $\begin{array}{l}\text { Produksi PPBBI } \\
\text { kg/tahun (pack/ } \\
\text { tahun) }\end{array}$ & $\begin{array}{l}1 \text { butir kelapa dapat dijadikan } 2 \\
\text { sampai } 3 \text { pack Kosudu. }\end{array}$ \\
\hline Strategi & Masih dalam skala internal di \\
\hline Pemasaran Saat ini & $\begin{array}{l}\text { Café Co-Choc PT RPN yang } \\
\text { menjual produk-produk hasil } \\
\text { riset perkebunan, serta } \\
\text { dipasarkan pula di PT Campina } \\
\text { Ice Cream Industry sebagai } \\
\text { bahan baku es krim kopyor. }\end{array}$ \\
\hline Pesaing & $\begin{array}{l}\text { Saat ini masih belum ada } \\
\text { pesaing, karena belum ada yang } \\
\text { mengembangkan produk kelapa } \\
\text { kopyor dalam bentuk beku. } \\
\text { Pasaran saat ini masih menjual } \\
\text { kelapa kopyor segar/batokan. }\end{array}$ \\
\hline
\end{tabular}
(2017) 
Menurut Vinifera (2006), kelapa kopyor merupakan komoditas bernilai ekonomi tinggi, namun sampai saat ini masih jarang dikembangkan sebagai komoditas andalan yang dipasarkan secara luas. The Delights of Indonesia Fruit adalah sebutan buah kelapa kopyor yang dicirikan oleh daging buah dengan tekstur gembur serta rasa yang gurih. Rasanya yang khas mampu bersaing dengan komoditas buah-buahan lainnya, sehingga komoditas kelapa kopyor ini mampu menjadi komoditas ekspor yang bisa diandalkan.

Sebelum teknologi kultur embrio in-vitro ditemukan, pengembangan kelapa kopyor masih sangat langka, karena berasal dari kelainan genetik, sehingga satu pohon kelapa normal hanya dapat menghasilkan kurang dari 10 persen per tandan buah kelapa kopyor. Sedangkan bibit kelapa kopyor hasil kultur embrio berpotensi menghasilkan tanaman kelapa kopyor sebesar 90\% sampai dengan 100\% Mashud et al. (2007). Saat penanaman kelapa kopyor hasil kultur embrio ini diterapkan pada perusahaan-perusahaan perkebunan, diperkirakan akan terjadi lonjakan pasokan kelapa kopyor yang begitu besar sehingga diperlukan strategi pemasaran yang tepat untuk dapat menyerap peningkatan produksi kelapa kopyor di masa yang akan datang.

Menurut Assael Thamrin, (2016) preferensi konsumen merupakan kesukaan, pilihan atau sesuatu hal yang lebih disukai konsumen untuk memutuskan membeli suatu produk. Sementara itu, Philip Kotler, (2000) menjelaskan bahwa preferensi konsumen menunjukkan kesukaan konsumen dari berbagai pilihan produk dan jasa yang ada. Untuk mempelajari preferensi konsumen, diperlukan kepahaman tentang perilaku konsumen yang menurut Schiffman \& Kanuk (2004) terpusat pada cara individu mengambil keputusan untuk memanfaatkan sumber daya yang tersedia: baik waktu, uang dan usaha untuk membeli barang-barang yang berhubungan dengan konsumsi. Hal ini mencangkup apa yang dibeli, kapan, dimana dan seberapa sering mereka membeli serta menggunakannya. Konsumen akan mengevaluasi serta mencari manfaat dari suatu produk hingga pada akhirnya konsumen membentuk preferensi atas produk tersebut dan berujung pada keputusan pembelian Kotler \& Keller (2007)
Salah satu rujukan yang relevan untuk mengkaji permasalahan ini adalah teori bauran pemasaran. Sebagimana diungkapkan oleh Kotler \& Keller (2007), bauran pemasaran merupakan suatu alat pemasaran yang digunakan perusahaan untuk mengejar tujuan perusahaannya. Bauran pemasaran ini sebenarnya telah disederhanakan dan sekaligus dipopulerkan oleh McCarthy (1968) menjadi (4P) yakni Product, Price, Place, dan Promotion. Sementara itu, kritik terhadap 4P telah membuat sebagian peneliti menciptakan model bauran pemasaran lainnya seperti yang diperkenalkan oleh Kotler \& Keller (2006) yakni (7P) Product, Price, Place, Promotion, People, Process, Physical Evidence. Namun, hingga saat ini model 4P masih tetap paling populer dan menjadi elemen kunci dalam sebagian besar literatur pemasaran. Oleh karena itu, penelitian ini tetap menggunakan model 4P dalam mengukur bauran pemasaran untuk merencanakan strategi pemasaran Kosudu pada masa yang akan datang.

Berikut ini akan dijelaskan secara ringkas variabel teori 4P tersebut McCarthy (1968):

1. Product / Produk: mengukur tingkat kesukaan konsumen terhadap rasa, kemasan, merek.

2. Price / Harga: mengukur tingkat kesukaan konsumen terhadap murahnya harga atau terjangkau.

3. Place / Tempat: mengukur tingkat kesukaan konsumen terhadap tempat yang strategis, mudah didapatkan dan tersedia parkir yang luas.

4. Promotion / Promosi: mengukur tingkat kesukaan konsumen terhadap bentuk promosi yang telah dilakukan, seperti: adanya potongan harga, tersedianya tester, dan iklan yang dilakukan.

Saat ini studi-studi tentang tanaman kelapa kopyor masih sangat terbatas di Indonesia, baik untuk budidaya maupun prospek pemasarannya. Padahal aspek bisnis dari budidaya kelapa kopyor sangat menjanjikan. Adapun tujuan dari penelitian ini adalah untuk mengetahui preferensi konsumen terhadap produk kelapa kopyor, khususnya Kosudu. Setelah mengetahui preferensi konsumen terhadap Kosudu, penelitian ini kemudian akan merumuskan strategi pemasaran yang tepat dengan melihat bauran pemasarannya. 


\section{METODE}

\section{LOKASI PENELITIAN}

Lokasi penelitian berada di wilayah Bogor tepatnya di Café Coffee and Chocolate Corner (CoChocs) PT Riset Perkebunan Nusantara dan pengumpulan data dilakukan secara convenience sampling dengan memberikan kuesioner kepada pembeli Kosudu yang pada saat itu membeli produk Kosudu di Café Coffee and Chocolate Corner (Co-Chocs) PT Riset Perkebunan Nusantara. Alasan dipilihnya Café Co-Chocs sebagai lokasi penelitian adalah karena sampai saat ini hanya Café tersebut yang menjual Kosudu dan memasarkan produk-produk hasil penelitian PT Riset Perkebunan Nusantara.

\section{METODE ANALISIS DATA}

Data yang terkumpul kemudian diolah menggunakan Microsoft Excel dalam bentuk grafik dan tabel untuk memudahkan penyajian data. Metode analisis yang digunakan adalah analisis deskriptif, yaitu memaparkan data yang relevan terhadap persepsi konsumen dan merumuskan strategi pemasaran sesuai dengan bauran pemasaran yang telah ditetapkan.

\section{PENGUMPULAN DATA}

Metode pengumpulan data dilakukan dengan cara (1) Pengamatan langsung dengan cara mempelajari berbagai dokumen penjualan dan proses pembelian konsumen; (2) Membuat daftar pertanyaan (kuesioner) dan wawancara. Kuesioner disebarkan kepada 50 orang responden yang merupakan konsumen sedang berbelanja Kosudu di Café Co-Chocs PT Riset Perkebunan Nusantara. Penelitian ini melakukan screening terlebih dahulu kepada responden dengan memastikan bahwa responden adalah konsumen yang sebelumnya pernah membeli atau mengkonsumsi produk olahan Kosudu. Sehubungan dengan jumlah populasi penelitian sulit untuk didapatkan dan adanya keterbatasan dalam menentukan kerangka sampling, maka pemilihan 50 responden dianggap sudah dapat mewakili populasi yang akan diamati.

\section{HASIL DAN PEMBAHASAN}

\section{PREFERENSI KONSUMEN}

Sebagaimana yang telah dijelaskan di bab pendahuluan, preferensi konsumen adalah kesukaan, pilihan atau sesuatu hal yang lebih disukai konsumen untuk memutuskan membeli suatu produk Assael (2016). Analisis preferensi konsumen adalah analisis yang bertujuan untuk mengetahui apa yang disukai dan tidak disukai konsumen, juga untuk menentukan urutan kepentingan dari suatu atribut produk maupun produk itu sendiri.

Dari 50 responden konsumen Kosudu, diperoleh data sebagai berikut:

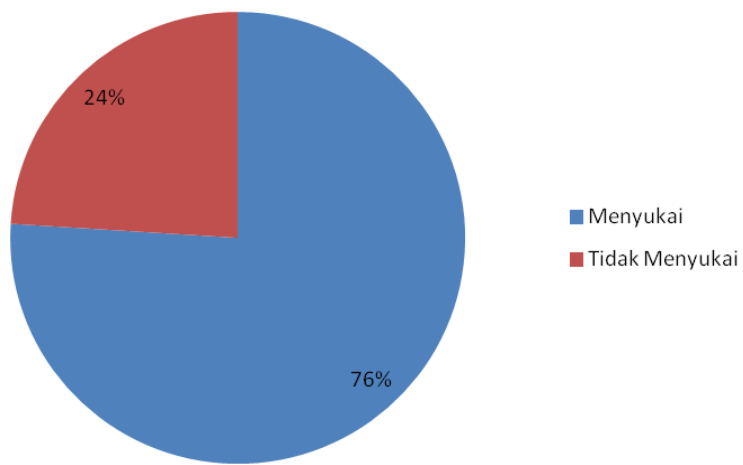

\section{Gambar 2. Preferensi Konsumen terhadap Kosudu \\ Sumber: data Primer diolah}

Terdapat 38 responden atau 76 persen konsumen menyatakan menyukai produk Kosudu dan memutuskan untuk membeli ulang Kosudu dengan urutan alasan sebagai berikut:

1. Kosudu Praktis, 27 orang responden: konsumen hanya perlu membeli Kosudu yang sudah berbentuk kemasan, dan tidak perlu repot untuk membuka kelapa).

2. Harga Kosudu murah, 20 orang responden: harga Kosudu dinilai lebih murah yakni Rp. 28.000/ pack sedangkan untuk kelapa kopyor batokan umumnya sekitar Rp. 35.000 sampai dengan 45.000/ butir.

3. Rasa Kosudu enak, 16 responden: rasa Kosudu dinilai sama dengan kelapa segar batokan walaupun dijual dalam bentuk beku. 
4. Tidak ada produk sejenis, 13 orang responden: menurut alasan yang dikemukakan sebagian konsumen, saat ini masih belum ada produk sejenis/ produk kelapa kopyor yang dijual dalam bentuk kemasan dan beku, maka suka tidak suka, tidak ada pilihan lain untuk konsumen dalam memilih produk lainnya.

5. Alasan lainnya, 10 orang responden, seperti: faktor tempat membeli Kosudu yang dekat dengan pusat kota Bogor, disukai oleh keluarga di rumah sebagai minuman favorit, dan tahan lama karena dapat disimpan di lemari pendingin (freezer) dalam waktu yang cukup lama tanpa menghilangkan kualitas rasa.

Sedangkan untuk 12 responden atau 24 persen konsumen menyatakan tidak menyukai produk Kosudu dan memutuskan untuk tidak membeli ulang atau berpikir untuk membeli ulang dengan alasan sebagai berikut:

1. Susah mendapatkan Kosudu, 10 responden: Kosudu hanya dijual di Café Co-Chocs PT Riset Perkebunan Nusantara, sulit bagi konsumen yang berdomisili atau beraktivitas di luar kota Bogor untuk dapat membeli Kosudu. Catatan: selama ini Kosudu tidak dijual dengan pengiriman online karena sifat dari Kosudu yang mudah meleleh.

2. Nama "Kosudu" yang kurang menarik, 8 responden: Dari hasil wawancara konsumen memberikan masukan untuk memberi nama produk yang mudah diingat dan memiliki keterkaitan akan produk itu sendiri.

3. Tidak terdapat promosi yang menarik, 6 responden: konsumen beranggapan bahwa selama ini belum ada promosi yang membuat konsumen ingin melakukan repeat order terhadap Kosudu, promosi yang dimaksud seperti: adanya potongan harga, beli satu gratis satu ataupun tester Kosudu, sehingga mendorong ketertarikan konsumen membeli.

4. Alasan lainnya, 5 responden, seperti: Kosudu tidak sesegar kelapa kopyor batokan, aroma/bau Kosudu yang agak tengik bila tidak disimpan di lemari pendingin (freezer), dan pelayanan Café Co-Chocs yang kurang ramah serta Kosudu yang kurang praktis dan quality control yang berubah-ubah.

\section{PENILAIAN KONSUMEN TERHADAP ATRIBUT PRODUK, HARGA, LOKASI DAN PROMOSI.}

Dalam merumuskan strategi pemasaran, peneliti menggunakan 4 atribut bauran pemasaran karya McCarthy (1968) yakni: Product atau Produk, Price atau Harga, Place atau Tempat Penjualan, dan Promotion atau Promosi.

Menggunakan penilaian skala, 1. Tidak setuju, 2. Netral, dan 3. Setuju. Responden diminta untuk menilai aspek bauran pemasaran yang ditinjau dari beberapa aspek seperti yang dipaparkan dalam diagram di bawah ini.

\section{Atribut Produk}

Tentang apakah konsumen menyukai produk Kosudu yang berhubungan dengan aspek: rasa, kemasan, dan merek.

Dari hasil penelusuran 50 responden diperoleh data sebagai berikut: 9 responden atau 18 persen menyukai produk Kosudu, 38 responden atau 76 persen netral, dan 3 responden atau 6 persen tidak menyukai produk Kosudu.

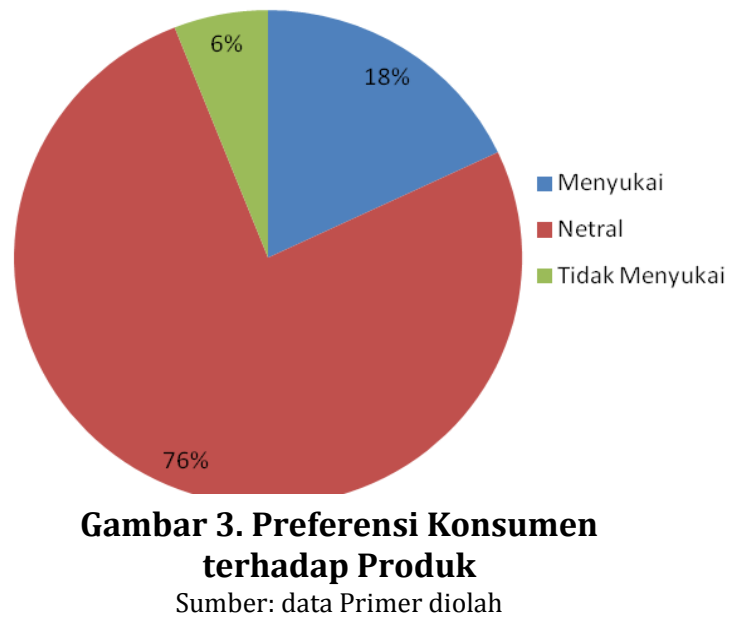

Ketika ditarik perhitungan dari masingmasing indikator produk, seperti rasa, kemasan dan merek maka diperoleh angka sebagai berikut. Pada indikator rasa 40 orang atau 80 persen responden menyukai rasa produk Kosudu, 8 responden atau 16 persen menjawab netral, dan sisanya yakni 2 orang atau 4 persen menjawab tidak menyukai produk Kosudu.

Pada indikator kemasan, 14 responden atau 28 persen menyukai kemasan Kosudu, 13 responden menjawab netral, dan 23 responden atau sekitar 46 persen responden tidak menyukai 
kemasan Kosudu. Sedangkan pada indikator merek, 17 responden atau sekitar 34 persen konsumen menjawab menyukai merek Kosudu, 8 responden atau 16 persen menjawab netral dan 25 responden atau sekitar 50 persen menjawab tidak menyukai merek Kosudu. Penjelasan pada ketiga indikator produk dapat dilihat pada gambar 4 di bawah ini.

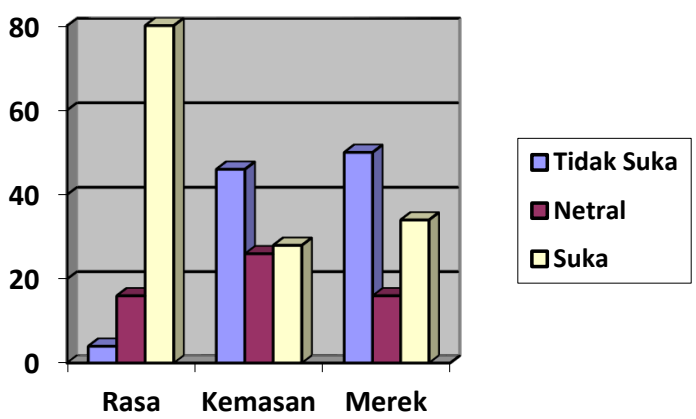

Gambar 4. Indikator Produk

Sumber: data Primer diolah

Dari grafik di atas dapat ditarik kesimpulan bahwa sebagian besar responden menyukai produk Kosudu, namun pada kemasan dan merek relatif banyak yang tidak menyukai. Menanggulangi hal tersebut perlu adanya pengembangan produk dari kemasan dan merek.

\section{Atribut Harga}

Tentang apakah konsumen menyukai harga dari Kosudu yang berhubungan dengan aspek harga terjangkau dan cenderung murah.

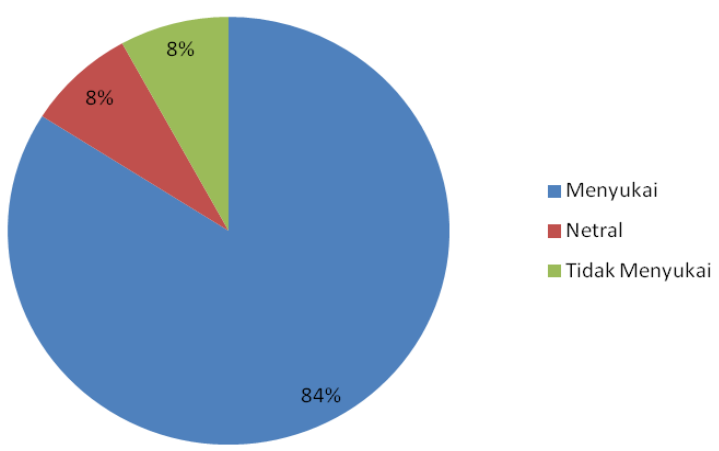

\section{Gambar 5. Preferensi Konsumen terhadap Harga \\ Sumber: data Primer diolah}

Gambar 5 menunjukkan bahwa dari hasil penelusuran 50 responden diperoleh data 42 responden atau 84 persen menyukai harga
Kosudu yang terbilang terjangkau dan murah, 4 responden atau sekitar 8 persen menyatakan netral, dan 4 responden lainnya, 8 persen menyatakan tidak setuju dan merekomendasikan penurunan harga.

\section{Atribut Lokasi}

Tentang apakah lokasi penjualan Kosudu di Café Co-Chocs PT RPN disukai oleh responden seperti lokasi penjualan yang strategis, mudah didapatkan, dan tempat parkir luas.

Dari hasil penelusuran 50 responden diperoleh data sebagai berikut: 5 responden atau sekitar 10 persen menyukai lokasi penjualan Kosudu, 27 responden atau sekitar 54 persen menjawab netral, dan 18 responden atau sekitar 36 persen menyatakan tidak menyukai lokasi penjualan Kosudu karena tidak strategis, tidak mudah didapatkan dengan penjualan online, dan tempat parkir yang kurang. Penjelasan pada atribut produk dapat ditinjau pada gambar 6 berikut :

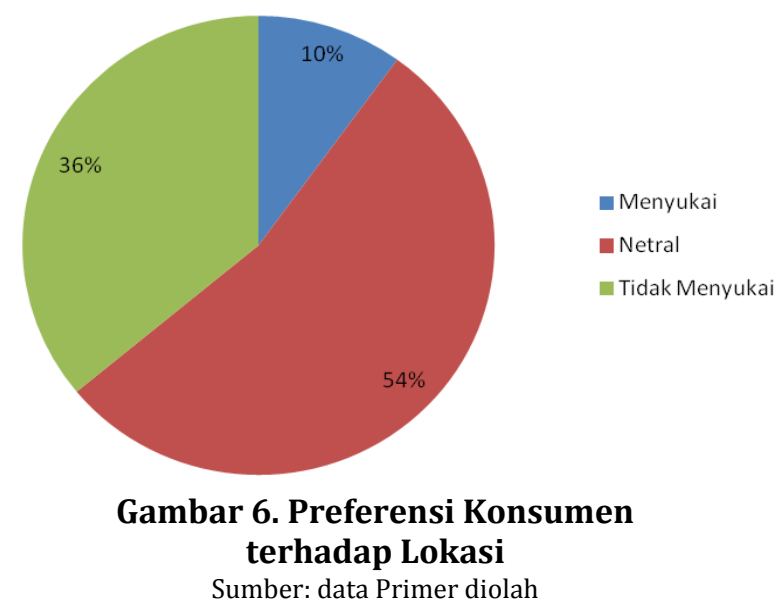

Pada atribut lokasi, peneliti menghitung masing-masing indikator seperti tempat yang strategis, barang mudah didapatkan, dan tempat parkir yang luas. 10 responden atau 20 persen menjawab menyukai lokasi penjualan Kosudu yang strategis, 15 responden atau 30 persen menjawab netral dan 25 responden atau 50 persen menjawab tidak menyukai lokasi penjualan Kosudu karena kurang strategis.

Pada indikator kemudahan mendapatkan produk 15 responden atau sekitar 30 persen menjawab Kosudu mudah di dapatkan, 4 responden atau sekitar 8 persen menjawab netral 
dan 31 responden atau sekitar 62 persen menjawab tidak menyukai produk Kosudu karena sulit didapatkan. Pada indikator kemudahan mencari tempat parkir 20 responden atau 40 persen menyatakan menyukai tempat parkir Kosudu, 3 responden atau sekitar 6 persen menyatakan netral, dan sisanya 27 responden atau sekitar 54 persen menjawab tidak menyukai ketersediaan tempat parkir Kosudu. Penjelasan pada masing-masing indikator lokasi tersedia dalam penjelasan pada gambar 7 berikut ini:

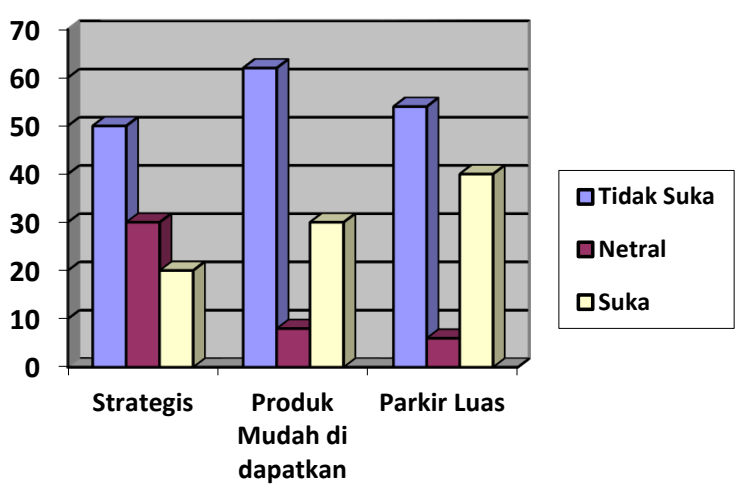

Gambar 7. Indikator Lokasi

Sumber: data Primer diolah

Dari gambar 7 dapat ditarik kesimpulan sebagai berikut: mayoritas responden tidak menyukai lokasi penjualan Kosudu yang hanya dapat dibeli di Café Co-Chocs PT Riset Perkebunan Nusantara. Responden beranggapan bahwa lokasi penjualan Kosudu kurang strategis, tidak mudah didapatkan, dan parkiran kurang luas.

\section{Atribut Promosi}

Tentang apakah promosi Kosudu yang dilihat dari indikator ketersediaan diskon, iklan, dan promosi lainnya seperti adanya tester dan buy one get one. Hasil penelusuran 50 responden diperoleh data sebagai berikut: Tidak ada responden yang menyukai promosi Kosudu, 20 responden atau 40 persen menyatakan netral, dan 30 orang atau sekitar 60 persen menyatakan tidak menyukai promosi Kosudu dapat dilihat pada gambar 8 berikut ini.

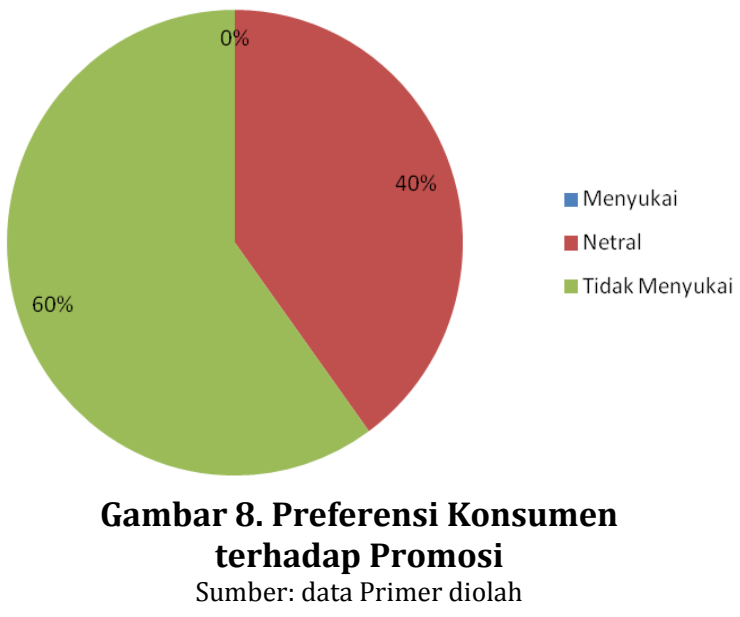

Ketika ditarik perhitungan pada masingmasing indikator, diperoleh data seperti di bawah ini. Pada indikator ketersediaan diskon 8 responden atau sekitar 16 persen menjawab menyukai diskon Kosudu, 8 responden atau sekitar 16 persen menyatakan netral, dan 34 responden atau sekitar 68 persen menyatakan tidak menyukai diskon Kosudu.

Pada indikator iklan, 1 responden atau sekitar 2 persen menyukai iklan Kosudu, 9 responden atau sekitar 18 persen menyatakan netral dan 40 responden atau sekitar 80 persen menyatakan tidak menyukai iklan Kosudu. Kebanyakan responden mengaku mengetahui Kosudu dari mulut-ke mulut, belum ada promosi yang dilakukan dengan gencar untuk menyebarluaskan produk. Pada indikator promosi lainnya seperti ketersediaan tester dan promosi buy one get one, 11 responden atau sekitar 22 persen menyatakan menyukai promosi lain yang ditawarkan Kosudu, 8 responden atau sekitar 16 persen menjawab netral, dan 31 responden atau sekitar 62 persen menyatakan tidak menyukai promosi Kosudu dalam bentuk lainnya, karena selama ini mereka tidak pernah mendapatkan tester dan promosi buy one get one Kosudu. Penjelasan pada masing-masing indikator dapat diperoleh pada Gambar 9.

Sebagaimana yang telah dibahas pada analisis di atas terdapat kesimpulan yang dapat ditarik dari gambar 9. Mayoritas responden mengungkapkan diskon Kosudu tidak sesuai dengan harapan mereka, begitu pula dengan iklan dan promosi lainnya. 


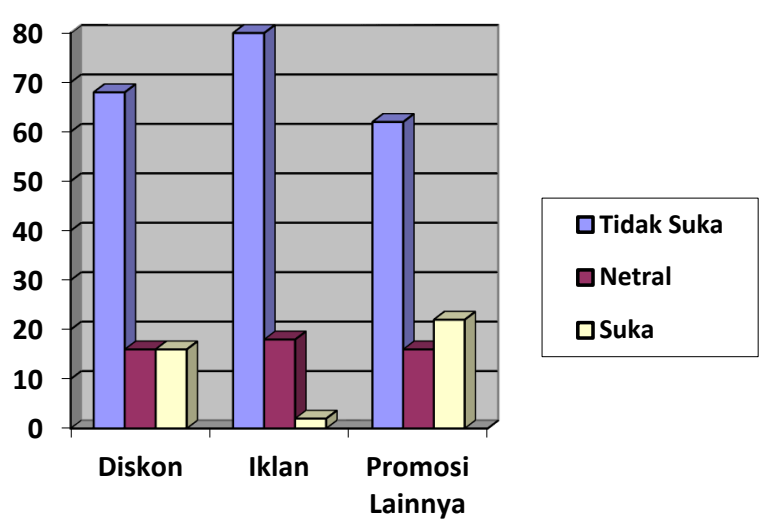

Gambar 9. Indikator Promosi

Sumber: data Primer diolah

\section{STRATEGI PENGEMBANGAN PEMASARAN KOSUDU}

Berdasarkan hasil analisis preferensi konsumen dan bauran pemasaran yang telah diuraikan di atas, peneliti menilai hanya tiga atribut Kosudu yang membutuhkan penanganan yang tepat untuk dapat diterima dengan baik, yakni: atribut produk, tempat dan promosi. Pada atribut harga peneliti menilai bahwa tidak diperlukan perubahan karena mayoritas konsumen menganggap harga Kosudu termasuk murah dan terjangkau. Strategi-strategi dalam pengem- bangan pemasaran Kosudu telah dirangkum Peneliti pada tabel 2.

Pada atribut produk diperlukan aspekaspek yang perlu diperbaiki seperti nama merek yang mudah diingat dan dikaitkan dan kontrol kualitas yang baik. Pada dunia bisnis global sendiri banyak perusahaan-perusahaan besar yang mengubah nama merek dagangnya dengan merek yang lain. Diungkapkan oleh Emerson (2017) Apple inc dulunya bernama Apple Computer, begitu pula perusahaan raksasa Google yang dulunya pernah memiliki merek dagang BackRub. Setiawan (2008) mengungkapkan bahwa ada 7 (tujuh) alasan mengapa perusahaan dapat mengganti nama merek. Pertama, asosiasi nama merek yang berpotensi merugikan merek, alasan yang. Kedua perubahan nama merek yang sesuai dengan asosiasi merek. Ketiga familiaritas merek. Keempat karena nama merek sebelumnya kurang berpeluang untuk dipakai pada produk di kategori produk lain (eksistensi merek). Kelima, nama merek sulit diucapkan dan tidak mampu mengasosiasikan produk yang diinginkan. Keenam, perubahan merek karena akuisisi perusahaan lain. Alasan terakhir karena munculnya alasan hukum pada nama merek.

Tabel 2. Strategi Pemasaran Kosudu

\begin{tabular}{|c|c|c|c|}
\hline Atribut & Item & Kelemahan & Strategi \\
\hline \multirow[t]{4}{*}{ Produk } & Merek & $\begin{array}{l}\text { Merek kurang menarik dan } \\
\text { sulit diingat. }\end{array}$ & $\begin{array}{l}\text { Mengganti nama merek dengan merek yang } \\
\text { lebih mudah diingat }\end{array}$ \\
\hline & Kemasan & Kemasan kurang menarik & Membuat Kemasan yang menarik \\
\hline & Praktis & $\begin{array}{l}\text { Kosudu kurang praktis, tidak } \\
\text { dapat langsung minum }\end{array}$ & $\begin{array}{l}\text { Berinovasi untuk membuat produk } \\
\text { minuman kelapa kopyor yang langsung } \\
\text { minum }\end{array}$ \\
\hline & $\begin{array}{l}\text { Quality } \\
\text { Control }\end{array}$ & $\begin{array}{l}\text { Rasa Kosudu kadang-kadang } \\
\text { berubah. }\end{array}$ & $\begin{array}{l}\text { Mempertahankan kualitas produk yang } \\
\text { baik dan tidak pernah berubah dari hari ke } \\
\text { hari. }\end{array}$ \\
\hline \multirow[t]{2}{*}{ Tempat } & $\begin{array}{l}\text { Online } \\
\text { Delivery }\end{array}$ & $\begin{array}{l}\text { Tidak terdapat sistem } \\
\text { pengiriman online. }\end{array}$ & $\begin{array}{l}\text { Jika online delivery tidak memungkinkan } \\
\text { karena sifat kopyor mudah mencair, } \\
\text { diperlukan pendekatan business to business. }\end{array}$ \\
\hline & $\begin{array}{l}\text { Perluasan } \\
\text { Penjualan }\end{array}$ & $\begin{array}{l}\text { Hanya dijual di Café Co- } \\
\text { Chocs PT RPN. }\end{array}$ & $\begin{array}{l}\text { Mulai melakukan kerja sama ke retail-retail } \\
\text { di dekat tempat produksi, misalnya } \\
\text { Indomaret dan Alfamart. }\end{array}$ \\
\hline \multirow[t]{3}{*}{ Promosi } & $\begin{array}{l}\text { Potongan } \\
\text { Harga }\end{array}$ & $\begin{array}{l}\text { Tidak pernah/ jarang } \\
\text { memberikan diskon }\end{array}$ & Memberikan diskon di hari-hari tertentu \\
\hline & Iklan & $\begin{array}{l}\text { Hanya mengetahui Kosudu } \\
\text { dari mulut-ke mulut }\end{array}$ & Menggencarkan iklan di media sosial \\
\hline & $\begin{array}{l}\text { Promosi } \\
\text { lainnya }\end{array}$ & $\begin{array}{l}\text { Belum adanya promosi yang } \\
\text { menarik. }\end{array}$ & $\begin{array}{l}\text { Menyediakan strategi promosi buy one get } \\
\text { one, tester dan atau sejenisnya untuk } \\
\text { menjaring calon pembeli. }\end{array}$ \\
\hline
\end{tabular}

Sumber: Data Pribadi diolah 
Selain itu pada segi kemasan harus dibuat lebih menarik. Misalnya saja saat ini kemasan Kosudu hanya berupa plastik aluminium yang kurang menarik. Pengembangan dalam segi kemasan sebelumnya juga pernah dilakukan oleh produk air mineral Aqua. Saat ini botol-botol kemasan Aqua dinilai lebih variatif sesuai dengan kebutuhan konsumen: contohnya saja botol yang didesain khusus untuk pelari, yang memiliki tutup botol yang sesuai. Sama halnya dengan unsur kepraktisan. Jika ingin lebih diterima oleh pasar sebaiknya mempertimbangkan inovasi produk yang lebih praktis yang dapat langsung diminum, karena saat ini Kosudu harus dicampur dengan es batu dan pemanis terlebih dahulu. Dalam hal quality control, seharusnya memang harus selalu diperhatikan dengan mempertahankan rasa produk yang tidak pernah berubah.

Disadur dari Mandari (2018), penjualan online dapat peningkatan penjualan sebesar 40$50 \%$ sehari pada produk-produk makanan yang dijual online. Hal ini karena kemudahan dan efektivitas waktu yang didapatkan oleh pembeli pada online delivery system. Pada atribut tempat penjualan disarankan untuk dapat diperbaiki seperti tersedianya penjualan dan pengiriman online, dan penjualan diperluas sehingga dapat ditemui di gerai-gerai lainnya, sehingga memudahkan konsumen untuk dapat memperoleh produk Kosudu. Namun, jika online delivery tidak memungkinkan untuk dijalankan karena sifat Kosudu yang cepat meleleh, pendekatan penjualan dapat dilakukan dengan cara business to business untuk melancarkan distribusi pemasaran kelapa kopyor/ Kosudu ke arah yang lebih besar, dan lebih cepat.

Pada atribut promosi, peneliti menilai perlu dilakukan bentuk promosi yang menarik untuk memasarkan Kosudu. Diungkapkan oleh Kartawijaya (2010) pada sebagian produk-baru promosi produk penting dilakukan untuk membuat ketertarikan konsumen terhadap produk tersebut. Contoh kasus yang paling mudah dilakukan adalah ketika peluncuran produk sampo TRESemme dari Unilever. Dulunya produk TRESemme tidak begitu dikenal dibandingkan dengan produk-produk Unilever yang lain. Dengan adanya promosi yang konsisten terhadap produk baru, yakni adanya potongan harga, iklan yang menarik dan promosi lainnya seperti buy one get one, saat ini produk TRESemme menjadi produk yang tidak kalah saing dengan produk Unilever lainnya. Demikian halnya dengan produk Kosudu, promosi harus digencarkan sebagai investasi pemasaran perusahaan. Iklan yang menarik melalui media sosial dirasa cocok untuk menyebarkan informasi produk, penggunaan iklan di media sosial khususnya Youtube, Instagram, Facebook, Twitter, dan lainnya dirasa cukup efektif dan efisien untuk mempromosikan produk sehingga dapat diketahui oleh khalayak yang lebih luas lagi, karena selama ini konsumen menilai hanya mengetahui produk Kosudu dari mulut-ke mulut.

\section{SIMPULAN DAN SARAN}

\section{SIMPULAN}

Dari hasil pembahasan dapat disimpulkan mayoritas responden menyatakan menyukai produk Kosudu dan memutuskan untuk melakukan pembelian ulang, sedangkan sebagian kecil menyatakan tidak menyukai produk Kosudu dan memutuskan untuk tidak melakukan pembelian ulang atau masih pikir-pikir dalam memutuskan pembelian dikemudian hari.

Adapun alasan-alasan yang mempengaruhi preferensi konsumen dalam melakukan pembelian ulang produk Kosudu adalah sebagai berikut: harga terjangkau, rasa Kosudu enak, tidak ada produk sejenis yang dijual di pasaran, dan alasan-alasan lainnya seperti tempat penjualan Kosudu yang berada di pusat kota Bogor. Sedangkan alasan-alasan yang mempengaruhi preferensi konsumen untuk tidak menyukai produk Kosudu dan tidak melakukan pembelian ulang adalah sebagai berikut: Kosudu susah didapatkan, nama produk Kosudu yang sulit diingat, promosi yang kurang serta alasan lainnya seperti: Kosudu tidak sesegar kelapa kopyor batokan, bau Kosudu yang tengik bila tidak disimpan di lemari pendingin (freezer), Kosudu yang kurang praktis dan quality control yang sering kali berubah dan pelayanan Café Co-Chocs yang kurang ramah.

Sedangkan pada aspek strategi penjualan kelapa kopyor, diperlukan perbaikan pada atribut product/produk, atribut place/tempat dan atribut 
promotion/promosi. Sedangkan pada atribut harga, dinilai tidak diperlukan perubahan karena mayoritas responden menganggap harga Kosudu sudah cukup terjangkau.

Pada atribut produk, aspek yang perlu diperhatikan adalah nama merek yang dianggap susah diingat dan tidak terkait dengan kelapa kopyor, kemasan yang kurang menarik, quality control Kosudu yang tidak menentu dan unsur Kosudu yang kurang praktis atau tidak dapat langsung minum.

Pada atribut lokasi penjualan, diperlukan adanya online delivery dan perluasan penjualan yang tidak hanya berfokus di Café Co-Chocs PT Riset Perkebunan Nusantara. Sedangkan pada atribut promosi diperlukan berbagai promosi yang menarik seperti potongan harga, iklan yang kekinian dan promosi lainnya.

\section{SARAN}

Dari hasil penelitian dapat disimpulkan bahwa adanya keinginan konsumen untuk disediakannya penjualan dalam bentuk online. Namun, karena sifat Kosudu yang tidak tahan lama tanpa lemari pendingin (freezer), peneliti merekomendasikan untuk dapat melakukan penjualan Kosudu dengan pendekatan business to business. Pendekatan business to business dapat menyasar kepada pabrik-pabrik penjualan es krim, restaurant-restaurant di Jabodetabek, ataupun tempat lainnya yang menggunakan kopyor sebagai bahan dasar produk yang dikembangkannya. Pendekatan business to business dapat dengan mudah menyerap produksi kelapa kopyor secara lebih besar, lebih cepat dan lebih tepat. Sedangkan untuk atribut promosi diperlukan promosi produk yang lebih gencar agar Kosudu mudah diketahui oleh konsumen, karena selama ini konsumen hanya mengetahui Kosudu dari mulut-ke mulut. Selain itu, potongan harga dan promosi lainnya perlu di lakukan di hari-hari tertentu agar dapat menarik minat konsumen dalam mencoba dan membeli ulang Kosudu.

Penelitian ini belum menggunakan alat analisis yang biasa digunakan untuk menganalisis preferensi, sehingga penelitan selanjutnya diharapkan dapat melakukan analisis sikap multiatribut dan IPA (Importance Performance Analysis) sehingga penelitian preferensi konsu- men terhadap kelapa kopyor menjadi lebih dalam dan spesifik.

\section{DAFTAR PUSTAKA}

Assael Thamrin. (2016). Buletin Pemasaran Universitas Ciputra, 8. Jakarta: Universitas Ciputra.

Direktorat Jenderal Perkebunan. (2013). Repositori Perkebunan. 8. Jakarta: Dirjenbun

Emerson, J. (2017). The Power of Branding, 9. Chicago: Chicago Press

Hutapea, R. (2007). Kelapa Kopyor dan Prosepeknya Kedepan. Buletin Palma Manado. Manado: Balai Penelitian Tanaman Palma.

Kartawijaya, H. (2010). The Power of Marketing Business. Jakarta: Gramedia Pustaka Utama.

Kotler \& Keller. (2006). Holistic Marketing, 6. New York: The New York Press.

Kotler \& Keller. (2007). Manajemen Pemasaran. Marketing Business, 12, 109-125. New York: The New York Journal

Mandari Euglena. (2018). Dahsyatnya Penjualan Online. In Kompas. Di Unduh 16 Juli 2018.

Mashud, Maskromo R, Hutapea H, N. (2007). Puslitbang Perkebunan. Tanaman Palma (Vol. 2). Maluku: Pusat Penelitian Tanaman Palma Press.

McCarthy, J. (1968). Marketing Attributes. Marketing Business, 2. Chicago: The Chicago Social Journal.

Philip Kotler. (2000). Marketing Global and The Key to Succes. Manajemen Pemasaran, 10, 154. Jakarta:Gramedia Pustaka Utama

Setiawan, B. (2008). Branding Strategy. Bogor: IPB Press

Schiffman \& Kanuk. (2004). Manajemen Marketing, Jakarta: Rajawali

Vinifera, N. (2006). Ketersediaan Kelapa Kopyor di Indonesia dan Pemasarannya. Ekonomi Dan Bisnis Institut Pertanian Bogor. Bogor: Repository IPB 